\title{
Expression and function of histamine and its receptors in atopic dermatitis
}

\author{
M. Albrecht and A. M. Dittrich ${ }^{*}$
}

\begin{abstract}
Background: Atopic dermatitis constitutes a most burdensome chronic inflammatory skin disease. Standard treatment is cumbersome and often targets its main symptom, pruritus, only insufficiently.

Findings: Recent advances in our understanding of the role of histamine and its four receptors suggest new approaches which target the histamine receptors alone or as combination therapies to more efficiently combat pruritus and inflammation in atopic dermatitis.

Conclusions: With this review, we provide an overview on histamine and the expression of its four receptors on skin resident and nonresident cells. Furthermore, we summarize recent studies which suggest anti-histamine therapy to efficiently combat pruritus and inflammation in atopic dermatitis and discuss possible approaches to incorporate these findings into more effective treatment strategies for atopic dermatitis in childhood.
\end{abstract}

Keywords: Atopic dermatitis, Histamine, Histamine receptors, Immunology, Treatment

\section{Introduction}

Atopic dermatitis (AD) is one of the most prevalent chronic diseases in early childhood. AD affects about $20 \%$ of all children [1] and can prevail into adulthood. Its severe pruritus, stigmatizing local appearance, and relapsing course turn it into a chronic disease with a heavy psychological burden on the affected families. Treatment is cumbersome and time-consuming, and pruritus can only be addressed insufficiently, mainly by improvements in overall disease control which cannot always be achieved.

Immunologically, AD is driven by TSLP-secretion by keratinocytes and epithelial cells which modulate dendritic cell (DC) and basophil function to preferentially induce a Th2 immune response. The Th2 associated cyto- and chemokines IL-4, IL-5, IL-13, TARC/CCL17, and MDC/CCL22, in turn, lead to recruitment of mast cells and eosinophils whose mediator release includes histamine [2, 3].

Plasma histamine levels are higher in $\mathrm{AD}$ patients than in healthy controls [4], and histamine is detected readily in $\mathrm{AD}$ skin lesions [5]. Histamine's pleiotropic actions were acknowledged since its discovery and since the 1960s attributed to the secretion by different cell types (Table 1) and the differential tissue expression of several

\footnotetext{
* Correspondence: Dittrich.Anna-Maria@mh-hannover.de Department for Pediatric Pneumology, Allergology and Neonatology, Hannover School of Medicine, Carl-Neuberg-Str. 1, 30625 Hannover, Germany
}

receptors (Table 2, [6, 7]). Four histamine receptors (HRs) have been described; thus far, the "youngest" of these receptors, the H4-receptor was discovered in 2000 only $[8,9]$. The first clinically used anti-histamine was synthesized in 1942, and ever since, anti-histamines have been a mainstay of anti-allergic, particularly anti-pruritic therapy mainly by targeting the H1R.

\section{Targeting histamine as a therapeutic approach for AD}

For a long time, histamine's effects in allergic skin disease were thought to be mediated solely by its action on H1Rs. In the skin, H1Rs are expressed on vascular smooth muscle cells, endothelial cells, neurons, and different immune cells such as monocytes, neutrophils, DCs, and T and B cells where their activation drives the typical symptoms of immediate hypersensitivity responses, comprising edema and pruritus [10]. Anti-H1R antagonism has been a mainstay of anti-allergic treatment regimens since the advent of the first anti-H1R antagonists by chemical synthesis. Their efficiency as anti-pruritic agents in urticaria and inclusion in the therapy of anaphylaxis are undisputed. The effects of H1R blockade in anaphylaxis critically depend on its vasoconstrictive properties. The anti-pruritic effects are mediated by a reduction of histamine-dependent release of pruritogenic pro-inflammatory mediators such as

\section{Springer}

(C) 2015 Albrecht and Dittrich. Open Access This article is distributed under the terms of the Creative Commons Attribution 4.0 International License (http://creativecommons.org/licenses/by/4.0/), which permits unrestricted use, distribution, and reproduction in any medium, provided you give appropriate credit to the original author(s) and the source, provide a link to the Creative Commons license, and indicate if changes were made. 
Table 1 Resident and nonresident cells of the skin capable of histamine secretion

\begin{tabular}{l}
\hline Cell type \\
\hline Neurons [110] \\
Basophils [111] \\
Mast cells [112] \\
Platelets [113] \\
DCs [114] \\
T cells [115] \\
Macrophages [51]
\end{tabular}

bradykinins, serotonin, prostaglandins, and substance $\mathrm{P}$ by mast cells which all can confer an itching sensation. Moreover, histamine regulates the release of nerve growth factor [11] and semaphorin 3A from keratinocytes which also act as pruritic factors, and H1R targeting reduces IL-31, a pro-pruritic cytokine which additionally plays an important role in skin barrier integrity $[12-14]$.

In addition to its pro-pruritic effect, several studies acknowledge a role for the H1R on immune cells in mediating inflammatory effects of allergic skin diseases with antagonism of the H1R by several drugs demonstrating anti-inflammatory properties in different experimental models of AD [15-19]. Thus, antagonism of histamine has the potential to affect pruritus as well as inflammation in AD. However, numerous clinical studies have shown that $\mathrm{AD}$ is only insufficiently addressed by antiH1Rs [20, 21] since no significant reduction in pruritus or disease severity over control was observed with topical or systemic treatment $[22,23]$. National guidelines thus do not recommend treatment with anti-H1R antagonists for the therapy of childhood AD anymore, neither systemically nor topically (AWMF S3 Leitlinie der deutschen dermatologischen Gesellschaft; [24]). However, as we will discuss below, new findings concerning the effect of histamine and HR expression in AD and AD models necessitate a re-thinking of the approaches used to target the histamine pathway in atopic skin disease and suggest new possibilities for anti-histamine therapy in AD.

\section{Histamine and histamine receptor expression in skin-resident and nonresident cells}

In this review, we provide the readers with a comprehensive summary of histamine and histamine receptor expression. In this context, we would like to caution that, as usual, antibody-dependent methods to determine expression levels depend on the antibody-specificity of the antibodies used and thus need to be received with the necessary prudence. As outlined above, a variety of cell types within the skin are capable of histamine secretion (Table 1). In turn, histamine can act on a variety of cell types in the skin due to the widespread expression of its four receptors on a large variety of cell types in the skin (Table 2).

\section{Mast cells, eosinophils, and basophils}

Quantitatively, mast cells and eosinophils are mainly responsible for histamine secretion in the skin. They can respond to histamine secretion due to the expression of different HRs (Tables 1 and 2). For eosinophils, differential migratory and anti-migratory effects of histamine have been described depending on its dose which differentially acts on H1Rs and H2Rs [25, 26]. Additionally, both eosinophil and mast cell migration into the skin are driven

Table 2 Expression of HRs in resident and nonresident cells of the skin

\begin{tabular}{|c|c|}
\hline Cell type & Histamine receptor expression \\
\hline Mast cells & $\mathrm{H} 1 \mathrm{R}[10], \mathrm{H} 4 \mathrm{R}[116,117]$ \\
\hline Eosinophils & $\mathrm{H} 1 \mathrm{R}[10], \mathrm{H} 2 \mathrm{R}, \mathrm{H} 3 \mathrm{R}[32,91,118,119] \mathrm{H} 4 \mathrm{R}[120,121]$ \\
\hline Basophils & $\mathrm{H} 4 \mathrm{R}[116,117]$ \\
\hline Neutrophils & $\operatorname{H1R}[10], \operatorname{H2R}[122,123], \operatorname{H} 4 \mathrm{R}[116,117]$ \\
\hline Dendritic cells & H1R [34], H2R [34], H3R [32, 19, 118, 119], H4R [33] \\
\hline Langerhans cells & H4R [35] \\
\hline Monocytes/macrophages & $\operatorname{H1R}[10], \operatorname{H2R}[122,123], \operatorname{H3R}[32,91,118,119], \operatorname{H} 4 \mathrm{R}[8]$ \\
\hline T cells & $\operatorname{H1R}[10], \operatorname{H2R}[122,123], \operatorname{H4R}[100,117,124]$ \\
\hline B cells & $\mathrm{H} 1 \mathrm{R}[10], \mathrm{H} 2 \mathrm{R}[122,123]$ \\
\hline Keratinocytes & $\mathrm{H} 1 \mathrm{R}[10], \mathrm{H} 2 \mathrm{R}[71]$ \\
\hline Endothelial cells & H1R [10], H2R [122, 123], H1R-H4R [74] \\
\hline Smooth muscle cells & H1R [10], H2R [122, 123] \\
\hline Fibroblasts & H1R [82] \\
\hline Neurons & H1R [10], H2R [122, 123], H3R [32, 91, 118, 119] \\
\hline
\end{tabular}


by H4Rs [26-28]. Basophils, similar to eosinophils and mast cells, show H4R-dependent chemotaxis [29]. Indeed, findings on the effects of histamine via H4Rs on mast cells and eosinophil migratory behavior were instrumental in suggesting that combination therapies with H1Rs and H4Rs could provide synergistic efficacy in atopic skin diseases.

\section{Neutrophils}

In the context of allergic late-phase reactions, neutrophils also infiltrate the skin lesions in AD and are sought to contribute to disease flares [30]. While expression of H1R, H2R, and H4R has been described on neutrophils (Table 2), for many functional studies on the effect of histamine on neutrophils, it remains unclear whether these effects can be attributed to a direct effect of histamine on neutrophils or is mediated by effects of histamine on other cells types, for instance mast cells, which in turn affect neutrophil functions. Furthermore, histamine's effects on neutrophils often show disparate results [31], suggesting that more research is needed to increase our understanding of histamine's effects on neutrophils and potential beneficial aspects in the context of AD.

\section{Dendritic cells and langerhans cells and macrophages}

In immune responses, histamine's action on dendritic cells and, in the skin, Langerhans cells (LC)s), which express all four histamine receptors (DCs [32-34]) or the H4R (LCs [35]), warrants special attention. DCs can often be found in close proximity of degranulated mast cells and histamine secretion by mast cells controls DC migration to the lymph nodes [36]. Contact hypersensitivity (CHS) reactions depend on the interaction of mast cells and DCs [37], and the mast cell-DC interaction is also critical in mediating tolerance to autologous antigens in the skin [38]. Vanbervliet et al. showed earlier on that H1R signaling is an important mediator for the induction of allergen-dependent AD-like lesions in murine skin [39]. Several studies have shown that HR signaling critically shapes the $\mathrm{T}$ cell repertoire by modulation of DC effects on T helper (Th) cell polarization. For example, signaling via $\mathrm{H} 1 \mathrm{R}$ on DCs promotes $\mathrm{T}$ helper type 1 (Th1) polarization whereas H2R signaling favors Th2 polarization and IL-10 secretion by DCs [40-44]. Furthermore, the same group showed that H1R signaling on DCs plays a critical role in the balance of IFN- $\gamma$ and IL-17 secretion, driving an AD phenotype in mice [45]. Gschwandtner et al. showed that IFN- $\gamma$ upregulates H4R expression on inflammatory DCs of $\mathrm{AD}$ patients and $\mathrm{H} 4 \mathrm{R}$ stimulation of these cells leads to reductions in TNF- $\alpha$ and IL-12 secretion [46]. In a CHS model which displays some features of $\mathrm{AD}$, blocking of the H4R led to decreased DC migration to the LNs, resulting in decreased Th2 and Th17 cytokine secretion $[47,48]$. In summary, these findings point towards a decisive role for histamine in modulating $\mathrm{DC} / \mathrm{LC}$ function to distinctively shape the $\mathrm{T}$ cell response in $\mathrm{AD}$.

In contrast to the development of DCs, during macrophage differentiation from monocytes $H 1 R$ is up- and $\mathrm{H} 2 \mathrm{R}$ downregulated $[49,50]$. Besides, macrophages are capable to produce and secrete histamine themselves [51]. Stimulation of lung macrophages by H1R leads to release of pro-inflammatory mediators like IL-6 [52], thereby amplifying an ongoing inflammatory response, a process which might also take place in the skin. Moreover, stimulation of the IgE specific receptor (FceRI) on human monocytes promotes differentiation into H1Rexpressing macrophages, which are pro-inflammatory and exhibit increased histamine secretion [53]. The same authors could prove that H1R-positive macrophages are present in AD lesions of the skin. Additionally, stimulation of the H4R increases chemotaxis and phagocytosis in murine bone marrow derived macrophages and a macrophage-like cell line [54] furthermore aggravating inflammation in AD. Antagonism of H1R and H4R might thus be a strategy to inhibit self-amplifying proinflammatory circles in skin macrophage function.

\section{T cells}

Polarized $\mathrm{T}$ cells display differential HR expression, which contribute to the polarization and activation status by histamine; Th1 cells express higher levels of H1R, while T helper type II (Th2) cells express higher levels of H2R. H1R stimulation is necessary for optimal IFN- $\gamma$ secretion $[55,56]$, increases Th1 proliferation, and has chemotactic effects on airway Th1 cells [57]. H1R knockout mice show enhanced secretion of Th2 cytokines and reduced severity of Th1-dependent autoimmune disease [58], pointing towards preferential Th1 activation by H1R. Moreover, triggering of H1R in allergic rhinitis patients increases Th2 cytokine secretion [59]. By resorting to differential H4R knockout mice, Hartwig et al. could elegantly show that via H4R signaling on DCs, the H4R is involved in T cell polarization towards a Th2 phenotype [60].

However, histamine's effects on T cells are pleiotropic, depending on the HR addressed. For example, histamine exerts immunoregulatory effects via the H2R encompassing different Th cells: H2R knockout mice display upregulation of both Th1 and Th2 cytokines [55] and triggering of the H2R enhances TGF- $\beta$-dependent suppression of Th2 responses and proliferation [61], reduces IL-12 secretion [62], and can induce IL-10 secretion by Th2 cells [63]. These results assign a critical role to the H2Rs in promoting peripheral tolerance, which is supported by studies with cells from bee keepers tolerant to bee venom which show H2R- 
dependent suppression of IL-4 secretion by $\mathrm{T}$ cells in favor of increases in IL-10 secretion [64]. Resistance to H2R's immunosuppressant properties and concomitant H1R-dependent Th2 activation as observed in patients with allergic rhinitis might underlie atopic disease manifestations and warrants further research [59].

Different studies also assign a role for histamine signaling on tolerance induction or reduction by direct HR activity on regulatory $\mathrm{T}$ cells (Tregs). In that line, triggering of the H1R on Tregs decreases their suppressive function which was associated with decreases in CD25 and FoxP3 expression [65] while H4R triggering stimulates Treg frequency [66] and migration and inhibits IL12 and CCL2 secretion [67]. To complicate the picture even further, substantially, less is known on the expression of HRs on newer T helper cell subsets such as Th9, Th17, or Th22 cells, as well as possible functional consequences of such expression. H4R expression on Th17 has been described, and histamine stimulation of these cells increased IL-17 secretion and overall activation [68], suggesting that these cells might also be efficiently targeted by H4R antagonists.

\section{B cells}

Histamine's effects on B cells have not received much attention thus far and the few studies that address this question do not well discern direct or indirect effects of histamine on B cells as they did not resort to B cellspecific knockouts and could thus be mediated by histamine's effects on T cells or DCs. In HR knockout models, histamine's effects on B cells seem to largely depend on the requirement for $\mathrm{T}$ cell help. For $\mathrm{T}$ cellindependent $\mathrm{B}$ cell proliferation and immunoglobulin secretion, histamine, via H1R, appears to have a positive regulatory role while the production of $\mathrm{T}$ cell-dependent antigens is suppressed via the H1R. Abolishment of H2R signaling, however, decreases the production of $\mathrm{T}$ celldependent immunoglobulin secretion by B cells [69].

\section{Keratinocytes}

Th polarization and differential activation of Th cells in the skin is also driven by HR expression on keratinocytes. Histamine increases the production of MCP-1, RANTES, and GM-CSF in keratinocytes [70], chemokines with known pro-inflammatory and Th2-promoting effects. Furthermore, H1R expression on keratinocytes has been shown to differentially regulate the production of Th1 vs. Th2 chemokines, providing a negative-feedback signal for an existing Th2-dominant inflammation by enhancing Th1 supporting chemokines and suppressing Th2 favoring chemokine secretion [71]. Histamine also has effects on other important keratinocyte functions which go awry in AD: it decreases the formation of tight junctions and the expression of filaggrin, processes essential for the maintenance of skin barrier function, and increases keratinocyte proliferation, leading to hyperkeratosis [72, 73].

\section{Endothelial cells}

One main action of histamine on endothelial cells is its role in increasing vascular permeability by inducing endothelial barrier dysfunction contributing to pathological processes like anaphylactic reactions. All four identified receptors (H1R-H4R) can be found on endothelial cells of dermal origin showing different subcellular distribution amongst the receptors [74]. The disruption of endothelial barrier function by histamine, however, seems to be mediated primarily through $\mathrm{H} 1 \mathrm{R}$ via the small GTPase RhoA and its associated kinase ROCK, as treatment with a ROCK inhibitor protects from anaphylactic shock in experimental models [75]. Another function of histamine is upregulation of P-selectin on endothelial cell of dermal origin, enabling recruitment of leukocytes and thus enhancing inflammation [76]. Endothelial cells can amplify the immune response by secretion of IL-6 and IL-8 [77, 78] and upregulation of TLR2 and TLR4 after activation with histamine [79]. Although the impact of histamine actions on endothelial cells in $\mathrm{AD}$ pathology has been described as minor, data describing a longer lasting change in epithelial barrier function due to histamine treatment in endothelial cells of dermal origin compared to endothelial cells from the umbilical vein or cardiac origin [74] might indicate a more important role. Moreover, histamine seems to have a pro-angiogenetic effect, since H1R signaling on umbilical cord endothelial cells promotes bFGF (basic fibroblast growth factor)-induced VEGF (vascular endothelial growth factor) secretion and in turn proliferation and tube formation [80].

\section{Smooth muscle cells/fibroblasts}

Besides the well-known involvment of histamine in the weal and flare reaction by acting on vascular smooth muscle cells via H1R [81], recent evidence exists that histamine can influence skin fibroblast differentiation into myofibroblasts and thus play a role in fibrotic events: Histamine inhibits TGF-beta-mediated expression of $\alpha$ SMA ( $\alpha$-smooth muscle actin) by fibroblasts. TGF-beta, however, induces downregulation of H1R on fibroblasts leading to a balance between TGFbeta-mediated and histamine-mediated actions [82]. More evidence for an important role of histamine in the fibrotic processes in the skin gives the work by Yang et al. who could show that histamine induces periostin (a profibrotic protein) production by primary dermal fibroblasts in an ERK1/2-mediated manner by activation of H1R [83]. An increased expression of periostin in lesional skin of $\mathrm{AD}$ patients is indeed 
described [84], rendering it possible that antagonism of H1R might influence histamine-induced tissue remodeling in AD.

\section{Neurons}

Specific neurons in the skin mediate histamine-induced itching sensations, mediated by specific conducting pathways $[85,86]$. Those skin innervating sensory neurons express the H1R [87], H3R, and H4R, and activation of $\mathrm{H} 1 \mathrm{R}$ and $\mathrm{H} 4 \mathrm{R}$ promotes pruritus further enhanced by H3R antagonism [88]. Histamine-induced pruritic signals are mediated via protein kinase $C \delta[89]$ and activation of TRPV1 (a nonselective catione channel) via activation of phospholipase A [90]. Also, in vivo and in vitro studies suggest that the H3R is involved in mediating neuro-inflammatory effects by neuro-immune interactions of nerves and T cells or mast cells [91, 92].

\section{New histamine-directed approaches}

The expression and effects of histamine-mediated signaling on skin-resident and nonresident cells, as discussed above, beg to re-evaluate the efficacy of histamine targeting in AD. Particularly, new studies which closer delineate the main cellular players in $\mathrm{AD}$, their histamineresponsiveness, and findings on the most recently discovered HR, the H4R, suggest that novel targeting strategies incorporating the H4R could be effective in targeting not only pruritus but also inflammation in this abundant pediatric skin disease.

In that line, targeting the $\mathrm{H} 4 \mathrm{R}$ has particular appeal due to its pro-Th2 effects. H4R antagonism, via modulation of DC activation, reduces Th2-driven airway inflammation [47, 48, 93]. Similarly, the H4R mediates Th2-dependent skin inflammation $[47,48]$ with H4R antagonists reducing TARC secretion by mast cells, thereby reducing Th2 activation and polarization [19]. Signaling via $\mathrm{H} 4 \mathrm{R}$ is also critically implied in a hapten-induced AD model [94]. These studies translate into other findings, showing that H4R antagonists are more efficient than other HR antagonists in suppressing allergen-induced pruritus [95] and H4R targeting has been shown to efficiently target inflammation and pruritus in different model systems [96-99], with the H4Rs anti-pruritic effect possibly relying on reduction of IL-31 secretion [100]. Furthermore, the H4R has been shown to mediate Th17-dependent inflammation in arthritis [101], suggesting that Th17-driven inflammation which has been associated with $\mathrm{AD}$ [102-105], particularly in acute skin lesions [106], can also be efficiently countered by H4R antagonists. The first clinical studies with JNJ39758979, a selective H4R antagonist, showed good clinical efficacy in reducing histamineinduced pruritus in healthy subjects [107] as well as in reducing itch severity and duration in patients with $A D$
[108]. Unfortunately, severe side effects occurred in two patients with this compound in the phase II trial, leading to termination of the study.

Combination therapy with H1R and H4R antagonists might be an even more powerful approach. In a $\mathrm{T}$ cell transfer model, the use of specific H1- and H4-receptor antagonists revealed a crucial role for $\mathrm{H1}$ - and $\mathrm{H} 4$ receptors for Th2 migration and cytokine secretion in a Th2-driven model of skin inflammation. While H1- and H4-receptor antagonists both reduced Th2 recruitment to the site of challenge, local cytokine responses in skindraining lymph nodes were only reduced by the combined application of $\mathrm{H} 1$ - and H4-receptor antagonists [109]. These results might explain why antagonism of H1R alone had no significant effects on the dermatitis in an AD model [97], but co-administration did affect inflammation as well as pruritus [19]. Dunford et al. demonstrated superiority of targeting the H4R for pruritus compared to blockade of H1R. However, in H4R knockout mice, they showed an additive effect of H1R antagonism on pruritus, results which also argue for a combination approach to achieve the most potent suppression of histamine's effects [95].

\section{Conclusions}

Taken together, a large number of in vitro and animal studies suggest combined H1R/H4R targeting to successfully address pruritus and inflammation, two closely inter-related symptoms of AD. Initial clinical trials with an H4R antagonist did show good efficacy with regard to pruritus, yet the side-effects encountered prevent its development as a marketable drug. Further improvements in chemical compounds targeting the $H 4 R$ are thus needed to assess the effect of H4R treatment alone or in conjunction with H1R antagonists on allergic skin inflammation and, provided efficacy, ultimately take them into clinical trials to assess their clinical potential in a disease which would clearly benefit from new therapeutic approaches.

\section{Abbreviations}

AD: atopic dermatitis; CHS: contact hypersensitivity; HR: histamine receptor; Th: T helper cell; Th1: T helper type I cell; Treg: regulatory T cell.

\section{Competing interests}

The authors declare that they have no competing interest.

\section{Authors' contributions}

The authors co-wrote the manuscript. Both authors read and approved the final manuscript.

Received: 20 June 2015 Accepted: 10 December 2015

Published online: 21 December 2015

\footnotetext{
References

1. Arkwright PD, Stafford JC, Sharma V (2014) Atopic dermatitis in children. J Allergy Clin Immunol Pract 2:388-95

2. Novak N, Bieber T, Leung DY (2003) Immune mechanisms leading to atopic dermatitis. J Allergy Clin Immunol 112:S128-39
} 
3. Saeki H, Tamaki K (2006) Thymus and activation regulated chemokine (TARC)/CCL17 and skin diseases. J Dermatol Sci 43:75-84

4. Imaizumi A, Kawakami T, Murakami F, Soma Y, Mizoguchi M (2003) Effective treatment of pruritus in atopic dermatitis using $\mathrm{H} 1$ antihistamines (second-generation antihistamines): changes in blood histamine and tryptase levels. J Dermatol Sci 33:23-9

5. Greaves MW (2005) Antihistamines in dermatology. Skin Pharmacol Physiol 18:220-9

6. Ash AS, Schild HO (1966) Receptors mediating some actions of histamine. Br J Pharmacol Chemother 27:427-39

7. Lovenberg TW, Roland BL, Wilson SJ, Jiang X, Pyati J, Huvar A, Jackson MR, Erlander MG (1999) Cloning and functional expression of the human histamine H3 receptor. Mol Pharmacol 55:1101-7

8. Morse KL, Behan J, Laz TM, West RE Jr, Greenfeder SA, Anthes JC, Umland S, Wan Y, Hipkin RW, Gonsiorek W, Shin N, Gustafson EL, Qiao X, Wang S, Hedrick JA, Greene J, Bayne M, Monsma FJ Jr (2001) Cloning and characterization of a novel human histamine receptor. J Pharmacol Exp Ther 296:1058-66

9. Oda T, Morikawa N, Saito Y, Masuho Y, Matsumoto S (2000) Molecular cloning and characterization of a novel type of histamine receptor preferentially expressed in leukocytes. J Biol Chem 275:36781-6

10. Togias A (2003) H1-receptors: localization and role in airway physiology and in immune functions. J Allergy Clin Immunol 112:S60-8

11. Kanda N, Watanabe S (2003) Histamine enhances the production of nerve growth factor in human keratinocytes. J Invest Dermatol 121:570-7

12. Dillon SR, Sprecher C, Hammond A, Bilsborough J, Rosenfeld-Franklin M, Presnell SR, Haugen HS, Maurer M, Harder B, Johnston J, Bort S, Mudri S, Kuijper JL, Bukowski T, Shea P, Dong DL, Dasovich M, Grant FJ, Lockwood L, Levin SD, LeCiel C, Waggie K, Day H, Topouzis S, Kramer J, Kuestner R, Chen Z, Foster D, Parrish-Novak J, Gross JA (2004) Interleukin 31, a cytokine produced by activated $T$ cells, induces dermatitis in mice. Nat Immunol 5:752-60

13. Raap U, Wichmann K, Bruder M, Stander S, Wedi B, Kapp A, Werfel T (2008) Correlation of IL-31 serum levels with severity of atopic dermatitis. J Allergy Clin Immunol 122:421-3

14. Sonkoly E, Muller A, Lauerma Al, Pivarcsi A, Soto H, Kemeny L, Alenius $H$, Dieu-Nosjean MC, Meller S, Rieker J, Steinhoff M, Hoffmann TK, Ruzicka T, Zlotnik A, Homey B (2006) IL-31: a new link between T cells and pruritus in atopic skin inflammation. J Allergy Clin Immunol 117:411-7

15. Akamatsu H, Makiura M, Yamamoto N, Yagami A, Shimizu Y, Matsunaga K (2006) The effect of fexofenadine on pruritus in a mouse model (HR-ADf) of atopic dermatitis. J Int Med Res 34:495-504

16. Higashi M, Ohsawa I, Oda F, Yamada Y, Kawana S, lida K, Mitsuishi T (2013) Histamine $\mathrm{H} 1$-receptor antagonistic drug olopatadine suppresses TSLP in atopic dermatitis model mice. Allergol Int 62:137-8

17. Murota H, El-latif MA, Tamura T, Amano T, Katayama I (2010) Olopatadine hydrochloride improves dermatitis score and inhibits scratch behavior in NC/Nga mice. Int Arch Allergy Immunol 153:121-32

18. Murota H, El-latif MA, Tamura T, Katayama I (2014) Olopatadine hydrochloride decreases tissue interleukin-31 levels in an atopic dermatitis mouse model. Acta Derm Venereol 94:78-9

19. Ohsawa $Y$, Hirasawa N (2012) The antagonism of histamine $\mathrm{H} 1$ and $\mathrm{H} 4$ receptors ameliorates chronic allergic dermatitis via anti-pruritic and anti-inflammatory effects in NC/Nga mice. Allergy 67:1014-22

20. Sher LG, Chang J, Patel IB, Balkrishnan R, Fleischer AB Jr (2012) Relieving the pruritus of atopic dermatitis: a meta-analysis. Acta Derm Venereol 92:455-61

21. Wahlgren CF, Hagermark O, Bergstrom R (1990) The antipruritic effect of a sedative and a non-sedative antihistamine in atopic dermatitis. $\mathrm{Br} J$ Dermatol 122:545-51

22. Berberian BJ, Breneman DL, Drake LA, Gratton D, Raimir SS, Phillips S, Sulica VI, Bernstein JE (1999) The addition of topical doxepin to corticosteroid therapy: an improved treatment regimen for atopic dermatitis. Int J Dermatol 38:145-8

23. Drake LA, Fallon JD, Sober A (1994) Relief of pruritus in patients with atopic dermatitis after treatment with topical doxepin cream. The Doxepin Study Group. J Am Acad Dermatol 31:613-6

24. Eichenfield LF, Tom WL, Berger TG, Krol A, Paller AS, Schwarzenberger $K$ Bergman JN, Chamlin SL, Cohen DE, Cooper KD, Cordoro KM, Davis DM, Feldman SR, Hanifin JM, Margolis DJ, Silverman RA, Simpson EL, Williams HC, Elmets CA, Block J, Harrod CG, Smith Begolka W, Sidbury R (2014) Guidelines of care for the management of atopic dermatitis: section 2. Management and treatment of atopic dermatitis with topical therapies. J Am Acad Dermatol 71:116-32
25. Clark RA, Sandler JA, Gallin JI, Kaplan AP (1977) Histamine modulation of eosinophil migration. J Immunol 118:137-45

26. Ling P, Ngo K, Nguyen S, Thurmond RL, Edwards JP, Karlsson L, Fung-Leung WP (2004) Histamine $\mathrm{H} 4$ receptor mediates eosinophil chemotaxis with cell shape change and adhesion molecule upregulation. Br J Pharmacol 142:161-71

27. Hofstra CL, Desai PJ, Thurmond RL, Fung-Leung WP (2003) Histamine H4 receptor mediates chemotaxis and calcium mobilization of mast cells. J Pharmacol Exp Ther 305:1212-21

28. Reher TM, Neumann D, Buschauer A, Seifert R (2012) Incomplete activation of human eosinophils via the histamine $\mathrm{H} 4$-receptor: evidence for ligand-specific receptor conformations. Biochem Pharmacol 84:192-203

29. Shiraishi Y, Jia Y, Domenico J, Joetham A, Karasuyama H, Takeda K, Gelfand EW (2013) Sequential engagement of FcepsilonRl on mast cells and basophil histamine H(4) receptor and FcepsilonRl in allergic rhinitis. J Immunol 190:539-48

30. Langeveld-Wildschut EG, Thepen T, Bihari IC, ven Reijsen FC, de Vries IJ, Bruijnzeel PL, Bruijnzeel-Koomen CA (1996) Evaluation of the atopy patch test and the cutaneous late-phase reaction as relevant models for the study of allergic inflammation in patients with atopic eczema. J Allergy Clin Immunol 98:1019-27

31. Ciz M, Lojek A (2013) Modulation of neutrophil oxidative burst via histamine receptors. Br J Pharmacol 170:17-22

32. Arrang JM, Drutel G, Garbarg M, Ruat M, Traiffort E, Schwartz JC (1995) Molecular and functional diversity of histamine receptor subtypes. Ann N Y Acad Sci 757:314-23

33. Dijkstra D, Stark H, Chazot PL, Shenton FC, Leurs R, Werfel T, Gutzmer R (2008) Human inflammatory dendritic epidermal cells express a functional histamine H4 receptor. J Invest Dermatol 128:1696-703

34. Ohtani T, Aiba S, Mizuashi M, Mollah ZU, Nakagawa S, Tagami H (2003) H1 and $\mathrm{H} 2$ histamine receptors are absent on Langerhans cells and present on dermal dendritic cells. J Invest Dermatol 121:1073-9

35. Gschwandtner M, Rossbach K, Dijkstra D, Baumer W, Kietzmann M, Stark H, Werfel T, Gutzmer R (2010) Murine and human Langerhans cells express a functional histamine $\mathrm{H} 4$ receptor: modulation of cell migration and function. Allergy 65:840-9

36. Dawicki W, Jawdat DW, Xu N, Marshall JS (2010) Mast cells, histamine, and IL-6 regulate the selective influx of dendritic cell subsets into an inflamed lymph node. J Immunol 184:2116-23

37. Otsuka A, Kubo M, Honda T, Egawa G, Nakajima S, Tanizaki H, Kim B, Matsuoka S, Watanabe T, Nakae S, Miyachi Y, Kabashima K (2011) Requirement of interaction between mast cells and skin dendritic cells to establish contact hypersensitivity. PLoS One 6:e25538

38. de Vries VC, Pino-Lagos K, Nowak EC, Bennett KA, Oliva C, Noelle RJ (2011) Mast cells condition dendritic cells to mediate allograft tolerance. Immunity 35:550-61

39. Vanbervliet B, Bendriss-Vermare N, Massacrier C, Homey B, de Bouteiller O, Briere F, Trinchieri G, Caux C (2003) The inducible CXCR3 ligands control plasmacytoid dendritic cell responsiveness to the constitutive chemokine stromal cell-derived factor 1 (SDF-1)/CXCL12. J Exp Med 198:823-30

40. Caron G, Delneste Y, Roelandts E, Duez C, Bonnefoy JY, Pestel J, Jeannin P (2001) Histamine polarizes human dendritic cells into Th2 cell-promoting effector dendritic cells. J Immunol 167:3682-6

41. Kitawaki T, Kadowaki N, Sugimoto N, Kambe N, Hori T, Miyachi Y, Nakahata T, Uchiyama T (2006) lgE-activated mast cells in combination with pro-inflammatory factors induce Th2-promoting dendritic cells. Int Immunol 18:1789-99

42. Mazzoni A, Young HA, Spitzer JH, Visintin A, Segal DM (2001) Histamine regulates cytokine production in maturing dendritic cells, resulting in altered T cell polarization. J Clin Invest 108:1865-73

43. Mcllroy A, Caron G, Blanchard S, Fremaux I, Duluc D, Delneste Y, Chevailler A, Jeannin P (2006) Histamine and prostaglandin E up-regulate the production of Th2-attracting chemokines (CCL17 and CCL22) and down-regulate IFN-gamma-induced CXCL10 production by immature human dendritic cells. Immunology 117:507-16

44. van der Pouw Kraan TC, Snijders A, Boeije LC, de Groot ER, Alewijnse AE, Leurs R, Aarden LA (1998) Histamine inhibits the production of interleukin-12 through interaction with $\mathrm{H} 2$ receptors. J Clin Invest 102:1866-73

45. Vanbervliet B, Akdis M, Vocanson M, Rozieres A, Benetiere J, Rouzaire P, Akdis CA, Nicolas JF, Hennino A (2011) Histamine receptor H1 signaling on dendritic cells plays a key role in the IFN-gamma/LL-17 balance in T cell-mediated skin inflammation. J Allergy Clin Immunol 127(943-53):e1-10

46. Gschwandtner M, Schakel K, Werfel T, Gutzmer R (2011) Histamine H(4) receptor activation on human slan-dendritic cells down-regulates their pro-inflammatory capacity. Immunology 132:49-56 
47. Cowden JM, Riley JP, Ma JY, Thurmond RL, Dunford PJ (2010) Histamine H4 receptor antagonism diminishes existing airway inflammation and dysfunction via modulation of Th2 cytokines. Respir Res 11:86

48. Cowden JM, Zhang M, Dunford PJ, Thurmond RL (2010) The histamine H4 receptor mediates inflammation and pruritus in Th2-dependent dermal inflammation. J Invest Dermatol 130:1023-33

49. Triggiani M, Petraroli A, Loffredo S, Frattini A, Granata F, Morabito P, Staiano Rl, Secondo A, Annunziato L, Marone G (2007) Differentiation of monocytes into macrophages induces the upregulation of histamine $\mathrm{H} 1$ receptor. J Allergy Clin Immunol 119:472-81

50. Wang KY, Arima N, Higuchi S, Shimajiri S, Tanimoto A, Murata Y, Hamada T, Sasaguri $Y$ (2000) Switch of histamine receptor expression from $\mathrm{H} 2$ to $\mathrm{H} 1$ during differentiation of monocytes into macrophages. FEBS Lett 473:345-8

51. Takamatsu S, Nakashima I, Nakano K (1996) Modulation of endotoxin-induced histamine synthesis by cytokines in mouse bone marrow-derived macrophages. J Immunol 156:778-85

52. Triggiani M, Gentile M, Secondo A, Granata F, Oriente A, Taglialatela M, Annunziato L, Marone G (2001) Histamine induces exocytosis and IL-6 production from human lung macrophages through interaction with $\mathrm{H} 1$ receptors. J Immunol 166:4083-91

53. Novak N, Peng WM, Bieber T, Akdis C (2013) FcepsilonRI stimulation promotes the differentiation of histamine receptor 1-expressing inflammatory macrophages. Allergy 68:454-61

54. Czerner CP, Klos A, Seifert R, Neumann D (2014) Histamine induces chemotaxis and phagocytosis in murine bone marrow-derived macrophages and RAW 264.7 macrophage-like cells via histamine H4-receptor. Inflamm Res 63:239-47

55. Jutel M, Klunker S, Akdis M, Malolepszy J, Thomet OA, Zak-Nejmark T, Blaser K, Akdis CA (2001) Histamine upregulates Th1 and downregulates Th2 responses due to different patterns of surface histamine 1 and 2 receptor expression. Int Arch Allergy Immunol 124:190-2

56. Noubade R, Milligan G, Zachary JF, Blankenhorn EP, del Rio R, Rincon M, Teuscher C (2007) Histamine receptor $\mathrm{H} 1$ is required for TCR-mediated p38 MAPK activation and optimal IFN-gamma production in mice. J Clin Invest 117:3507-18

57. Bryce PJ, Mathias CB, Harrison KL, Watanabe T, Geha RS, Oettgen HC (2006) The $\mathrm{H} 1$ histamine receptor regulates allergic lung responses. J Clin Invest 116:1624-32

58. Ma RZ, Gao J, Meeker ND, Fillmore PD, Tung KS, Watanabe T, Zachary JF, Offner H, Blankenhorn EP, Teuscher C (2002) Identification of Bphs, an autoimmune disease locus, as histamine receptor H1. Science 297:620-3

59. Botturi K, Lacoeuille Y, Vervloet D, Magnan A (2010) Histamine induces Th2 activation through the histamine receptor 1 in house dust mite rhinitic but not asthmatic patients. Clin Exp Allergy 40:755-62

60. Hartwig C, Munder A, Glage S, Wedekind D, Schenk H, Seifert R, Neumann D (2015) The histamine $\mathrm{H} 4$-receptor (H4 R) regulates eosinophilic inflammation in ovalbumin-induced experimental allergic asthma in mice. Eur J Immunol 45:1129-40

61. Kunzmann S, Mantel PY, Wohlfahrt JG, Akdis M, Blaser K, Schmidt-Weber CB (2003) Histamine enhances TGF-beta1-mediated suppression of Th2 responses. FASEB J 17:1089-95

62. Elenkov IJ, Webster E, Papanicolaou DA, Fleisher TA, Chrousos GP, Wilder RL (1998) Histamine potently suppresses human IL-12 and stimulates IL-10 production via $\mathrm{H} 2$ receptors. J Immunol 161:2586-93

63. Osna N, Elliott K, Khan MM (2001) Regulation of interleukin-10 secretion by histamine in TH2 cells and splenocytes. Int Immunopharmacol 1:85-96

64. Meiler F, Zumkehr J, Klunker S, Ruckert B, Akdis CA, Akdis M (2008) In vivo switch to IL-10-secreting $T$ regulatory cells in high dose allergen exposure. J Exp Med 205:2887-98

65. Forward NA, Furlong SJ, Yang Y, Lin TJ, Hoskin DW (2009) Mast cells down-regulate CD4+ CD25+ T regulatory cell suppressor function via histamine $\mathrm{H} 1$ receptor interaction. J Immunol 183:3014-22

66. del Rio R, Noubade R, Saligrama N, Wall EH, Krementsov DN, Poynter ME, Zachary JF, Thurmond RL, Teuscher C (2012) Histamine H4 receptor optimizes $T$ regulatory cell frequency and facilitates anti-inflammatory responses within the central nervous system. J Immunol 188:541-7

67. Morgan RK, McAllister B, Cross L, Green DS, Kornfeld H, Center DM, Cruikshank WW (2007) Histamine 4 receptor activation induces recruitment of FoxP3+ T cells and inhibits allergic asthma in a murine model. J Immunol 178:8081-9

68. Mommert S, Gschwandtner M, Koether B, Gutzmer R, Werfel T (2012) Human memory Th17 cells express a functional histamine $\mathrm{H} 4$ receptor. Am J Pathol 180:177-85
69. Yanai K, Son LZ, Endou M, Sakurai E, Watanabe T (1998) Targeting disruption of histamine $\mathrm{H} 1$ receptors in mice: behavioral and neurochemical characterization. Life Sci 62:1607-10

70. Giustizieri ML, Albanesi C, Fluhr J, Gisondi P, Norgauer J, Girolomoni G (2004) H1 histamine receptor mediates inflammatory responses in human keratinocytes. J Allergy Clin Immunol 114:1176-82

71. Fujimoto S, Komine M, Karakawa M, Uratsuji H, Kagami S, Tada Y, Saeki H, Ohtsuki M, Tamaki K (2011) Histamine differentially regulates the production of Th1 and Th2 chemokines by keratinocytes through histamine $\mathrm{H} 1$ receptor. Cytokine 54:191-9

72. Glatzer F, Gschwandtner M, Ehling S, Rossbach K, Janik K, Klos A, Baumer W Kietzmann M, Werfel T, Gutzmer R (2013) Histamine induces proliferation in keratinocytes from patients with atopic dermatitis through the histamine 4 receptor. J Allergy Clin Immunol 132:1358-67

73. Gschwandtner M, Mildner M, Mlitz V, Gruber F, Eckhart L, Werfel T, Gutzmer R, Elias PM, Tschachler E (2013) Histamine suppresses epidermal keratinocyte differentiation and impairs skin barrier function in a human skin model. Allergy 68:37-47

74. Adderley SP, Zhang XE, Breslin JW (2015) Involvement of the H1 histamine receptor, p38 MAP kinase, myosin light chains kinase, and Rho/ROCK in histamine-induced endothelial barrier dysfunction. Microcirculation 22:237-48

75. Mikelis CM, Simaan M, Ando K, Fukuhara S, Sakurai A, Amornphimoltham P, Masedunskas A, Weigert R, Chavakis T, Adams RH, Offermanns S, Mochizuki N, Zheng Y, Gutkind JS (2015) RhoA and ROCK mediate histamine-induced vascular leakage and anaphylactic shock. Nat Commun 6:6725

76. Miyazaki Y, Satoh T, Nishioka K, Yokozeki H (2006) STAT-6-mediated control of P-selectin by substance $P$ and interleukin- 4 in human dermal endothelial cells. Am J Pathol 169:697-707

77. Delneste $Y$, Lassalle $P$, Jeannin $P$, Joseph M, Tonnel AB, Gosset $P$ (1994) Histamine induces IL-6 production by human endothelial cells. Clin Exp Immunol 98:344-9

78. Jeannin P, Delneste $Y$, Gosset P, Molet S, Lassalle P, Hamid Q, Tsicopoulos A, Tonnel AB (1994) Histamine induces interleukin-8 secretion by endothelial cells. Blood 84:2229-33

79. Talreja J, Kabir MH, B. Filla M, Stechschulte DJ, Dileepan KN (2004) Histamine induces Toll-like receptor 2 and 4 expression in endothelial cells and enhances sensitivity to Gram-positive and Gram-negative bacterial cell wall components. Immunology 113:224-33

80. Lu Q, Wang C, Pan R, Gao X, Wei Z, Xia Y, Dai Y (2013) Histamine synergistically promotes bFGF-induced angiogenesis by enhancing VEGF production via $\mathrm{H} 1$ receptor. J Cell Biochem 114:1009-19

81. White MV (1990) The role of histamine in allergic diseases. J Allergy Clin Immunol 86:599-605

82. Lin L, Yamagata K, Nakayamada S, Sawamukai N, Yamaoka K, Sakata K, Nakano K, Tanaka Y (2015) Histamine inhibits differentiation of skin fibroblasts into myofibroblasts. Biochem Biophys Res Commun 463:434-9

83. Yang L, Murota H, Serada S, Fujimoto M, Kudo A, Naka T, Katayama I (2014) Histamine contributes to tissue remodeling via periostin expression. J Invest Dermatol 134:2105-13

84. Hoffjan S, Epplen JT (2005) The genetics of atopic dermatitis: recent findings and future options. J Mol Med (Berl) 83:682-92

85. Andrew D, Craig AD (2001) Spinothalamic lamina I neurons selectively sensitive to histamine: a central neural pathway for itch. Nat Neurosci 4:72-7

86. Schmelz M, Schmidt R, Bickel A, Handwerker HO, Torebjork HE (1997) Specific C-receptors for itch in human skin. J Neurosci 17:8003-8

87. Han L, Ma C, Liu Q, Weng HJ, Cui Y, Tang Z, Kim Y, Nie H, Qu L, Patel KN, Li Z, McNeil B, He S, Guan Y, Xiao B, Lamotte RH, Dong X (2013) A subpopulation of nociceptors specifically linked to itch. Nat Neurosci 16:174-82

88. Rossbach K, Nassenstein C, Gschwandtner M, Schnell D, Sander K, Seifert R, Stark H, Kietzmann M, Baumer W (2011) Histamine H1, H3 and H4 receptors are involved in pruritus. Neuroscience 190:89-102

89. Valtcheva MV, Davidson S, Zhao C, Leitges M, Gereau RW 4th (2015) Protein kinase Cdelta mediates histamine-evoked itch and responses in pruriceptors. Mol Pain 11:1

90. Shim WS, Tak MH, Lee MH, Kim M, Kim M, Koo JY, Lee CH, Kim M, Oh U (2007) TRPV1 mediates histamine-induced itching via the activation of phospholipase A2 and 12-lipoxygenase. J Neurosci 27:2331-7

91. Dimitriadou V, Rouleau A, Dam Trung Tuong M, Newlands GJ, Miller HR, Luffau G, Schwartz JC, Garbarg M (1994) Functional relationship between mast cells and $\mathrm{C}$-sensitive nerve fibres evidenced by histamine $\mathrm{H} 3$-receptor modulation in rat lung and spleen. Clin Sci (Lond) 87:151-63 
92. Teuscher C, Subramanian M, Noubade R, Gao JF, Offner H, Zachary JF, Blankenhorn EP (2007) Central histamine $\mathrm{H} 3$ receptor signaling negatively regulates susceptibility to autoimmune inflammatory disease of the CNS. Proc Natl Acad Sci U S A 104:10146-51

93. Dunford PJ, O'Donnell N, Riley JP, Williams KN, Karlsson L, Thurmond RL (2006) The histamine $\mathrm{H} 4$ receptor mediates allergic airway inflammation by regulating the activation of CD4+ T cells. J Immunol 176:7062-70

94. Hirasawa N, Ohsawa Y, Katoh G, Shibata K, Ishihara K, Seyama T, Tamura S, Hong J, Ohuchi K (2009) Modification of the picryl chloride-induced allergic dermatitis model in mouse ear lobes by 12-0-tetradecanoylphorbol 13-acetate, and analysis of the role of histamine in the modified model. Int Arch Allergy Immunol 148:279-88

95. Dunford PJ, Williams KN, Desai PJ, Karlsson L, McQueen D, Thurmond RL (2007) Histamine $\mathrm{H} 4$ receptor antagonists are superior to traditional antihistamines in the attenuation of experimental pruritus. J Allergy Clin Immunol 119:176-83

96. Matsushita A, Seike M, Okawa H, Kadawaki Y, Ohtsu H (2012) Advantages of histamine $\mathrm{H} 4$ receptor antagonist usage with $\mathrm{H} 1$ receptor antagonist for the treatment of murine allergic contact dermatitis. Exp Dermatol 21:714-5

97. Rossbach K, Wendorff S, Sander K, Stark H, Gutzmer R, Werfel T, Kietzmann M, Baumer W (2009) Histamine H4 receptor antagonism reduces hapten-induced scratching behaviour but not inflammation. Exp Dermatol 18:57-63

98. Seike M, Furuya K, Omura M, Hamada-Watanabe K, Matsushita A, Ohtsu H (2010) Histamine $\mathrm{H}(4)$ receptor antagonist ameliorates chronic allergic contact dermatitis induced by repeated challenge. Allergy 65:319-26

99. Suwa E, Yamaura K, Oda M, Namiki T, Ueno K (2011) Histamine H(4) receptor antagonist reduces dermal inflammation and pruritus in a hapten-induced experimental model. Eur J Pharmacol 667:383-8

100. Gutzmer R, Mommert S, Gschwandtner M, Zwingmann K, Stark H, Werfel T (2009) The histamine $\mathrm{H} 4$ receptor is functionally expressed on $\mathrm{T}(\mathrm{H}) 2$ cells. J Allergy Clin Immunol 123:619-25

101. Cowden JM, Yu F, Banie H, Farahani M, Ling P, Nguyen S, Riley JP, Zhang M, Zhu J, Dunford PJ, Thurmond RL (2014) The histamine H4 receptor mediates inflammation and Th17 responses in preclinical models of arthritis. Ann Rheum Dis 73:600-8

102. Batista DI, Perez L, Orfali RL, Zaniboni MC, Samorano LP, Pereira NV, Sotto MN, Ishizaki AS, Oliveira LM, Sato MN, Aoki V (2015) Profile of skin barrier proteins (filaggrin, claudins 1 and 4) and Th1/Th2/Th17 cytokines in adults with atopic dermatitis. J Eur Acad Dermatol Venereol 29:1091-5

103. Dhingra N, Guttman-Yassky E (2014) A possible role for IL-17A in establishing Th2 inflammation in murine models of atopic dermatitis. J Invest Dermatol 134:2071-4

104. Narbutt J, Wojtczak M, Zalinska A, Salinski A, Przybylowska-Sygut K, Kuna P, Majak P, Sysa-Jedrzejowska A, Lesiak A (2015) The AVA genotype of an interleukin-17A polymorphism predisposes to increased severity of atopic dermatitis and coexistence with asthma. Clin Exp Dermatol 40:11-6

105. Roesner LM, Heratizadeh A, Begemann G, Kienlin P, Hradetzky S, Niebuhr M, Eiz-Vesper B, Hennig C, Hansen G, Baron-Bodo V, Moingeon P, Werfel T (2015) Der p1 and Der p2-specific T cells display a Th2, Th17, and Th2/Th17 phenotype in atopic dermatitis. J Invest Dermatol 135(9):2324-7

106. Koga C, Kabashima K, Shiraishi N, Kobayashi M, Tokura Y (2008) Possible pathogenic role of Th17 cells for atopic dermatitis. J Invest Dermatol 128:2625-30

107. Kollmeier A, Francke K, Chen B, Dunford PJ, Greenspan AJ, Xia Y, Xu XL, Zhou B, Thurmond RL (2014) The histamine H(4) receptor antagonist, JN 39758979 , is effective in reducing histamine-induced pruritus in a randomized clinical study in healthy subjects. J Pharmacol Exp Ther 350:181-7

108. Ohsawa $\mathrm{Y}$, Hirasawa N (2014) The role of histamine $\mathrm{H} 1$ and $\mathrm{H} 4$ receptors in atopic dermatitis: from basic research to clinical study. Allergol Int 63:533-42

109. Mahapatra S, Albrecht M, Behrens B, Jirmo A, Behrens G, Hartwig C, Neumann D, Raap U, Bahre H, Herrick C, Dittrich AM (2014) Delineating the role of histamine-1- and -4-receptors in a mouse model of Th2-dependent antigen-specific skin inflammation. PLoS One 9:e87296

110. Glick G, Wechsler AS, Epstein SE (1968) Mechanisms of reflex vasodilation: assessment of the role of neural reuptake of norepinephrine and release of histamine. J Clin Invest 47:511-20

111. Shelley WB, Juhlin L (1962) In vitro effect of licithinase A on the cytology of the human basophil. J Lab Clin Med 60:589-97

112. Fawcett DW (1954) Cytological and pharmacological observations on the release of histamine by mast cells. J Exp Med 100:217-24
113. Saxena SP, Brandes LJ, Becker AB, Simons KJ, LaBella FS, Gerrard JM (1989) Histamine is an intracellular messenger mediating platelet aggregation. Science 243:1596-9

114. Jutel M, Akdis M, Akdis CA (2009) Histamine, histamine receptors and their role in immune pathology. Clin Exp Allergy 39:1786-800

115. Kubo Y, Nakano K (1999) Regulation of histamine synthesis in mouse CD4+ and CD8+ T lymphocytes. Inflamm Res 48:149-53

116. Nakamura M, Zhao ZQ, Clark KL, Velez DV, Guyton RA, Vinten-Johansen J (2000) A novel adenosine analog, AMP579, inhibits neutrophil activation, adherence and neutrophil-mediated injury to coronary vascular endothelium. Eur J Pharmacol 397:197-205

117. Zhu YK, Liu XD, Skold CM, Umino T, Wang HJ, Spurzem JR, Kohyama T, Ertl RF, Rennard SI (2001) Synergistic neutrophil elastase-cytokine interaction degrades collagen in three-dimensional culture. Am J Physiol Lung Cell Mol Physiol 281:L868-78

118. Arrang JM, Garbarg M, Schwartz JC (1983) Auto-inhibition of brain histamine release mediated by a novel class $(\mathrm{H} 3)$ of histamine receptor. Nature 302:832-7

119. Gbahou F, Rouleau A, Morisset S, Parmentier R, Crochet S, Lin JS, Ligneau X, Tardivel-Lacombe J, Stark H, Schunack W, Ganellin CR, Schwartz JC, Arrang JM (2003) Protean agonism at histamine $\mathrm{H} 3$ receptors in vitro and in vivo. Proc Natl Acad Sci U S A 100:11086-91

120. Nakamura T, Itadani H, Hidaka Y, Ohta M, Tanaka K (2000) Molecular cloning and characterization of a new human histamine receptor, HH4R. Biochem Biophys Res Commun 279:615-20

121. Zhu Y, Michalovich D, Wu H, Tan KB, Dytko GM, Mannan IJ, Boyce R, Alston J, Tierney LA, Li X, Herrity NC, Vawter L, Sarau HM, Ames RS, Davenport CM, Hieble JP, Wilson S, Bergsma DJ, Fitzgerald LR (2001) Cloning, expression, and pharmacological characterization of a novel human histamine receptor. Mol Pharmacol 59:434-41

122. Kobayashi T, Inoue I, Jenkins NA, Gilbert DJ, Copeland NG, Watanabe T (1996) Cloning, RNA expression, and chromosomal location of a mouse histamine $\mathrm{H} 2$ receptor gene. Genomics 37:390-4

123. Traiffort E, Vizuete ML, Tardivel-Lacombe J, Souil E, Schwartz JC, Ruat M (1995) The guinea pig histamine $\mathrm{H} 2$ receptor: gene cloning, tissue expression and chromosomal localization of its human counterpart. Biochem Biophys Res Commun 211:570-7

124. Sugata Y, Okano M, Fujiwara T, Matsumoto R, Hattori H, Yamamoto M, Nishibori M, Nishizaki K (2007) Histamine H4 receptor agonists have more activities than $\mathrm{H} 4$ agonism in antigen-specific human T-cell responses. Immunology 121:266-75

\section{Submit your manuscript to a SpringerOpen ${ }^{\odot}$ journal and benefit from:}

- Convenient online submission

- Rigorous peer review

- Immediate publication on acceptance

- Open access: articles freely available online

- High visibility within the field

- Retaining the copyright to your article

Submit your next manuscript at $>$ springeropen.com 